\title{
Physical Growth and Retinopathy in Preterm Infants: Involvement of IGF-I and GH
}

\author{
SHUNJI HIKINO, KENJI IHARA, JUNKO YAMAMOTO, YASUSHI TAKAHATA, \\ HIDEKI NAKAYAMA, NAOKO KINUKAWA, YOKO NARAZAKI, AND TOSHIRO HARA \\ Department of Pediatrics [S.H., K.I., J.Y., Y.T., H.N., T.H.], Medical Informatics [N.K.], and \\ Ophthalmology [Y.N.], Graduate School of Medical Sciences, Kyushu University, Fukuoka, Japan
}

\begin{abstract}
ABSTR
GH and IGF-I are important for physical growth. We mea-
sured serum levels of these factors in preterm infants. The study
population $(n=81)$ was divided into three groups according to
the gestational age. We evaluated differences in serum GH and
IGF-I levels among groups with regard to physical growth and
development of retinopathy of prematurity. Serum GH levels in
extremely preterm infants born at $<28$ wk of gestational age
were significantly higher than levels in those born between 28
and 34 wk at 1 and 2 mo of age. In contrast, serum IGF-I levels
in extremely preterm infants remained low, whereas those in the
other two groups gradually increased. Evaluation of the effects of
GH and IGF-I on physical growth in very low birth weight
infants ( $<1500$ g) showed that IGF-I concentrations were posi-
tively related to physical growth for several months after birth,
\end{abstract}
Intrauterine and postnatal growth is affected by genetic, nutritional, hormonal, and environmental factors (1, 2). Growth factors derived from placental and maternal tissues have profound effects on fetal growth. Especially, GH and IGFs play an important role in regulation of fetal growth. Disruption of IGF-I, IGF-II, or their receptor genes in mice results in intrauterine growth retardation $(3,4)$. In humans, homozygous defect of the IGF-I gene was associated with growth failure before and after birth (5), and there was a positive correlation between cord blood IGF-I concentration and fetal growth or newborn birth weight $(6,7)$. During postnatal period, hormonal factors such as insulin and IGF-I largely contribute to the regulation of physical growth in addition to exogenous factors (8). With regard to preterm or extremely preterm infants, physical growth may be additionally influenced by immaturity of organs, neonatal diseases, and a variety of medical treatments (1).

$\mathrm{GH}$ is essential for the balanced growth of organs and body compositions in children. GH levels are higher in fetuses and

Received January 4, 2001; accepted June 26, 2001.

Correspondence and reprint requests: Kenji Ihara, MD, Department of Pediatrics, Graduate School of Medical Sciences, Kyushu University, 3-1-1 Maidashi, Higashi-ku, Fukuoka 812-8582, Japan; e-mail: k-ihara@mailserver.med.kyushu-u.ac.jp

Supported by grants from the Ministry of Education, Science, Sports and Culture of Japan, and the Foundation for Growth Science in Japan. whereas no relationship was observed between GH and physical growth. Multivariate analysis demonstrated that high GH concentration at 1 mo of age was significantly associated with development of severe retinopathy of prematurity. In conclusion, persistent low serum IGF-I levels may explain the slow physical growth during neonatal life, and exposure of high GH may cause, at least in part, severe retinopathy of prematurity in preterm infants. (Pediatr Res 50: 732-736, 2001)

Abbreviations
ROP, retinopathy of prematurity
SDS, SD score
VEGF, vascular endothelial growth factor

newborns than in children and adults (9). Especially in preterm infants, remarkably high $\mathrm{GH}$ and low IGF-I values in serum continue until $1 \mathrm{y}$ of age $(10-12)$. However, the growth effect of $\mathrm{GH}$ does not become apparent until about 18 mo of age, and the clinical significance of $\mathrm{GH}$ for perinatal growth has not been well understood (1).

Besides the effect on physical growth, GH has various biologic functions. It has been postulated that $\mathrm{GH}$ plays a role in initiating and sustaining angiopathic processes. In previous reports, the association between $\mathrm{GH}$ exposure and ischemia-induced retinal neovascularization was determined in diabetic patients (13-16). Accordingly, it is likely that continuous exposure to high $\mathrm{GH}$ causes progression of ROP in preterm infants. To the best of our knowledge, however, there have been no reports on the association between serum $\mathrm{GH}$ levels and physical growth or development of ROP in preterm infants.

We performed serial determinations of serum GH and IGF-I levels in preterm infants for several months after birth. Then, we have investigated whether GH or IGF-I levels influence the physical growth during neonatal period, and evaluated the development and severity of ROP in preterm infants.

\section{METHODS}

Study population. Preterm infants born at $<35$ wk of gestational age in Kyushu University hospital between 1995 and 
1998 were enrolled in this study. Infants with chromosomal aberrations and major morphologic anomalies, such as congenital heart diseases and brain anomalies, were excluded from this study. This study was approved by the Kyushu University Hospital Ethics Committee, and informed consent was obtained from the infants' parents. Gestational ages ranged from 24 to $34 \mathrm{wk}$, and birth weights, from 505 to $2196 \mathrm{~g}$. Infants were divided into three groups according to their gestational age: group A included infants born from 24 to $27 \mathrm{wk}$ of gestational age (29 infants; median birth weight, $854 \mathrm{~g}$ ); group B, born from 28 to 31 wk (33 infants; median birth weight, $1366 \mathrm{~g}$ ); and group C, born from 32 to 34 wk (19 infants; median birth weight, $1620 \mathrm{~g}$; Table 1).

Sample preparation. The sample collection was performed initially within $24 \mathrm{~h}$ after birth and before any medical treatment, and afterward, monthly during hospitalization. Samples of venous blood were collected at approximately 0800 at the time of routine hematologic or biochemical studies just before the intake of milk. Sera were immediately separated by centrifugation at $3000 \mathrm{rpm}$ for $10 \mathrm{~min}$ at $4^{\circ} \mathrm{C}$ and stored at $-30^{\circ} \mathrm{C}$ until assay.

Measurement of GH and IGF-I. Serum GH concentrations (in nanograms per milliliter) were measured by RIA using the assay kit from Daiichi Isotope Research Institute (Tokyo, Japan). The sensitivity of the assay was $0.1 \mathrm{ng} / \mathrm{mL}$, and the intraassay and interassay coefficients of variation were less than $1.3 \%$ and $2.1 \%$, respectively. Serum IGF-I levels (in nanograms per milliliter) were measured by RIA kit from Bayer Medical Corp (Tokyo, Japan). The sensitivity of the assay was $6.3 \mathrm{ng} / \mathrm{mL}$, and the intraassay and interassay coefficients of variation were less than $3.3 \%$ and $7.0 \%$, respectively.

Evaluation of the growth variables. We routinely checked the weight of each baby almost every day, whereas we measured the babies' length at birth, and thereafter, every month during hospitalization. SDS for body length and weight of very low birth weight infants $(<1500 \mathrm{~g} ; n=45)$ were calculated because a standard growth chart for the population of low birth weight infants only is presently available (17). The growth rates of length and weight were shown as $\triangle$ SDS-length and $\Delta$ SDS-weight values, respectively, which indicate the changes of SDS per month. IGF-I values of several points except those at birth were used to calculate the mean values of serum IGF-I levels in individual infants.

Ophthalmologic examinations. All the preterm infants in this study repeatedly underwent ophthalmologic examinations, and the condition of neovascular proliferation was evaluated according to the international criteria for ROP (Table 1) (18).

Statistical analyses. We evaluated differences of clinical factors among groups using $\chi^{2}$ test or Kruskal-Wallis test. All results of serum GH and IGF-I values in respective groups were expressed as the median values with ranges, and statistical analysis was performed using the Mann-Whitney $U$ test for comparison between two groups of GH or IGF-I values. The correlations between GH and IGF-I, or between $\triangle$ SDS-length or $\triangle$ SDSweight and IGF-I, were evaluated using linear regression analysis. For the study of the association between GH and ROP, the likelihood ratio test was performed. We also executed tests for trends in proportions at every point by the Mantel-Haenszel procedure, by dividing all patients into two groups. Values of $p<$ 0.05 were considered to be significant for all statistical tests.

\section{RESULTS}

Longitudinal evaluation of serum $\mathbf{G H}$. Serum GH levels at birth were remarkably high in all groups in comparison with those at 1, 2, or 3 mo of age (Fig. 1A). GH values of infants of groups $\mathrm{B}$ and $\mathrm{C}$ gradually declined after birth, whereas those in group A were persistently high until 3 mo after birth. Comparison of each value among groups demonstrated that groups $\mathrm{A}$ and $\mathrm{B}$ showed significantly higher serum GH levels than group $\mathrm{C}$ at 1 mo of age (A versus $\mathrm{C}, p=0.010$; $\mathrm{B}$ versus $\mathrm{C}$, $p=0.028$, respectively), and that group A had higher values than groups $\mathrm{B}$ and $\mathrm{C}$ at 2 mo of age (A versus $\mathrm{B}, p=0.0009$; A versus $\mathrm{C}, p=0.0053$, respectively). In addition, when $\mathrm{GH}$ levels at 30,34 , and $38 \mathrm{wk}$ of postconceptional age were evaluated, serum GH level in group A was also significantly higher than that in group $\mathrm{B}$ or $\mathrm{C}$ at 38 wk of postconceptional age (A versus $\mathrm{B}, p=0.0029$; A versus $\mathrm{C}, p=0.032$, respectively; Fig. 1B).

Table 1. Clinical profiles and ophthalmologic evaluation of study population

\begin{tabular}{|c|c|c|c|c|}
\hline Characteristic & Group A $(n=29)$ & Group B $(n=33)$ & Group C $(n=19)$ & $p$ value \\
\hline Gestational age (wk)* & $26[24-27]$ & $30[28-31]$ & $32[32-34]$ & \\
\hline \multicolumn{5}{|l|}{ Clinical profiles } \\
\hline Male:Female & 19:10 & $17: 16$ & $10: 9$ & 0.4946 \\
\hline CLD & 27 & 4 & 0 & $<0.0001$ \\
\hline Blood transfusion & 25 & 3 & 0 & $<0.0001$ \\
\hline stage 1 & 11 & 9 & 3 & \\
\hline stage 2 & 5 & 0 & 1 & \\
\hline stage 3 & 10 & 5 & 0 & \\
\hline stage 4 & 2 & 0 & 0 & \\
\hline
\end{tabular}

* Median [range].

$\dagger$ Evaluated by Kruskal-Wallis test; others by $\chi^{2}$ test.

Abbreviations used: CLD, chronic lung disease; NE, not examined. 
Longitudinal evaluation of serum IGF-I. Serum IGF-I levels in all groups of infants did not significantly differ at birth (Fig. 2). Thereafter, serum IGF-I level in group C gradually increased, whereas that in group A remained low for at least 3 mo after birth. When we compared serum IGF-I levels among groups, the IGF-I level in group A was significantly lower than that in group $\mathrm{B}$ or $\mathrm{C}$ at 1 and 2 mo after birth (at 1 mo: A versus $\mathrm{B}, p<0.0001$; A versus $\mathrm{C}, p<0.0001$; at 2 mo: A versus $\mathrm{B}$, $p=0.0036$; A versus $\mathrm{C}, p<0.0001$ ). At 3 mo of age, serum IGF-I level in group A was also lower than that in group $\mathrm{B}(p$ $=0.041$; Fig. $2 A$ ).

Evaluation of the IGF-I level with respect to postconceptional age demonstrated that IGF-I level in group A was also remarkably low from birth at least until $38 \mathrm{wk}$ of postconceptional age. When IGF-I levels among groups were compared at 30, 34, and $38 \mathrm{wk}$ of postconceptional age, the IGF-I level in group A was significantly lower than that in group B or C at 30,34 , and $38 \mathrm{wk}$ of postconceptional age (30 wk: group A versus $\mathrm{B}, p=0.0023 ; 34$ wk: A versus $\mathrm{B}, p<0.0001$; A versus $\mathrm{C}, p=0.015$; 38 wk: A versus $\mathrm{B}, p=0.0029$; A versus $\mathrm{C}, p=0.032$; Fig. $2 B$ ).

\section{A}

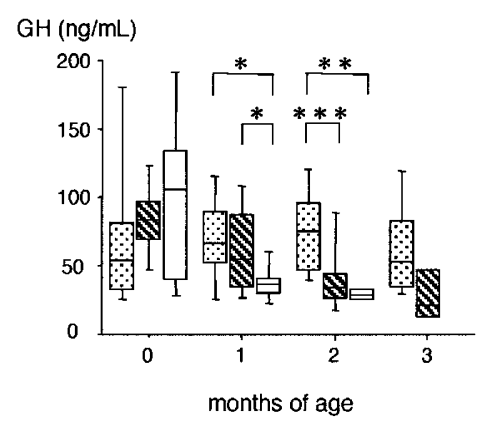

B

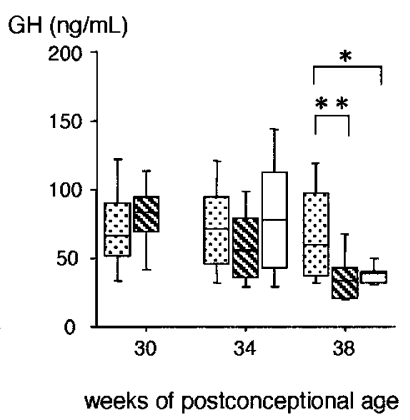

Figure 1. Serum $\mathrm{GH}$ concentrations in preterm infants. $A, \mathrm{GH}$ levels at birth, 1,2 , and 3 mo of age. $B, \mathrm{GH}$ levels at 30,34 , and $38 \mathrm{wk}$ of postconceptional age. Boxes represent the interquartile range (25th to 75 th percentiles), and lines within the boxes are the median; bars represent the upper (90th percentile) and the lower (10th percentile) adjacent values. Dotted, hatched, and open boxes demonstrate serum $\mathrm{GH}$ values of groups $\mathrm{A}, \mathrm{B}$, and $\mathrm{C}$, respectively. ${ }^{*} p<0.05$; $* * p<0.01 ; * * * p<0.001$.
A

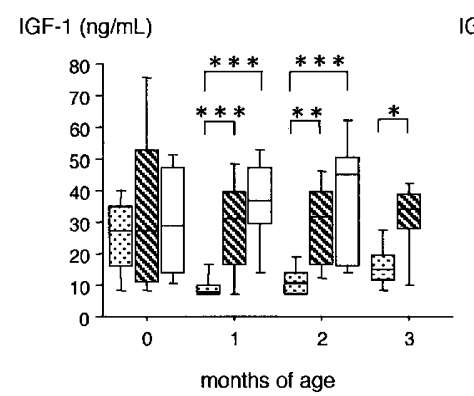

B

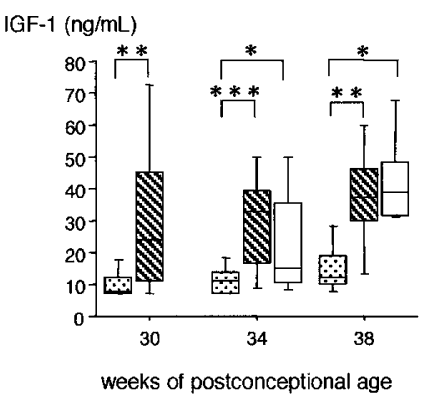

Figure 2. Serum IGF-I concentrations in preterm infants. $A$, IGF-I levels at birth, 1, 2, and 3 mo of age. B, IGF-I levels at 30, 34, and 38 wk of postconceptional age. Boxes represent the interquartile range (25th to 75 th percentiles), and lines within the boxes are the median; bars represent the upper (90th percentile) and the lower (10th percentile) adjacent values. Dotted, hatched, and open boxes demonstrate the serum IGF-I values of groups A, B, and $\mathrm{C}$, respectively. Symbols are the same as shown in Figure 1.

Correlation between GH and IGF-I. GH levels were negatively correlated with IGF-I levels at $1\left(r^{2}=0.28, p<0.0001\right.$; Fig. $3 A)$ and $2 \mathrm{mo}\left(r^{2}=0.34, p=0.0001\right.$; Fig. $\left.3 B\right)$ of age, but not at 3 mo of age because of the small sample number. On the other hand, GH and IGF-I levels showed a similar correlation at $38 \mathrm{wk}$ of postconceptional age $\left(r^{2}=0.25, p=0.0012\right)$, but not at birth or at 30 and $34 \mathrm{wk}$ (data not shown).

Relationship between IGF-I and growth rate during early infancy. Very low birth weight infants showed that mean values of serum IGF-I levels were positively related to the $\Delta$ SDS-length $\left(p=0.013, r^{2}=0.144\right)$, but not to the $\Delta$ SDSweight $\left(p=0.14, r^{2}=0.052\right)$, irrespective of their gestational ages (Fig. 4). There was no relationship between serum GH levels at any age and $\Delta$ SDS-length $\left(p=0.51, r^{2}=0.012\right)$ or $\Delta$ SDS-weight $\left(p=0.23, r^{2}=0.014\right)$.

Relationship between GH and ROP. The ophthalmologic evaluation showed that the more immature the infants were, the more frequently they developed more severe ROP (Table 1). The multivariate analysis demonstrated that high GH level at 1 mo of age was an independent risk factor for the development of severe ROP (Table 2). To exclude a possible influence of immaturity itself on the severity of ROP, we reevaluated the effect of high GH on the severity of ROP by dividing the whole
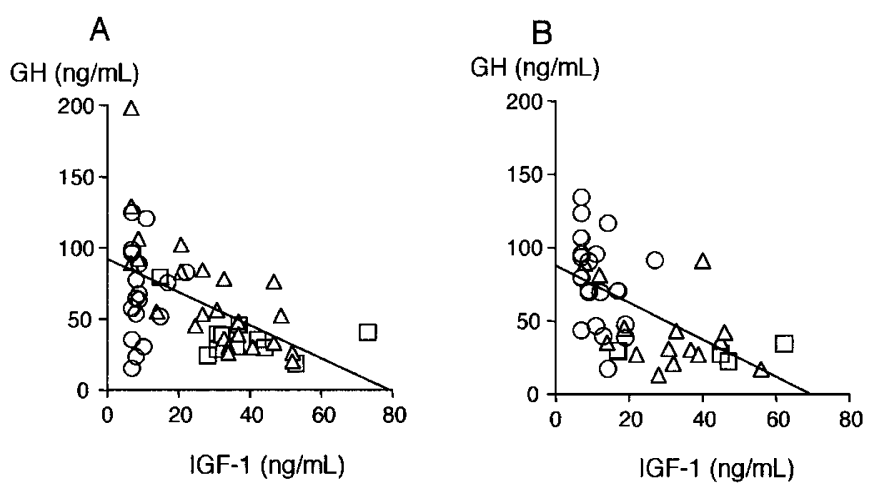

Figure 3. Correlations between serum GH and IGF-I levels. $A$, at 1 mo of age. $B$, at 2 mo of age. Negative correlations between serum GH and IGF-I levels are seen at both ages $\left(1 \mathrm{mo}, r^{2}=0.28, p<0.0001 ; 2 \mathrm{mo}, r^{2}=0.34, p=\right.$ $0.0001)$. Open circles, triangles, and squares demonstrate individuals belonging to groups $\mathrm{A}, \mathrm{B}$, and $\mathrm{C}$, respectively.

A

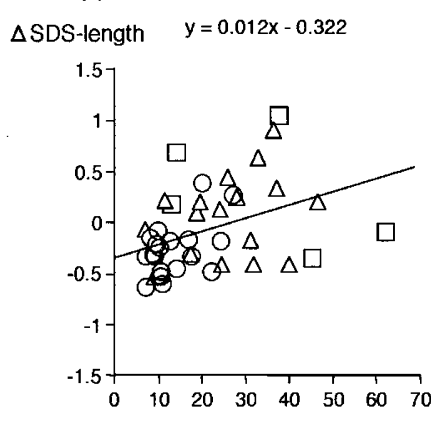

IGF-1 (ng/mL)

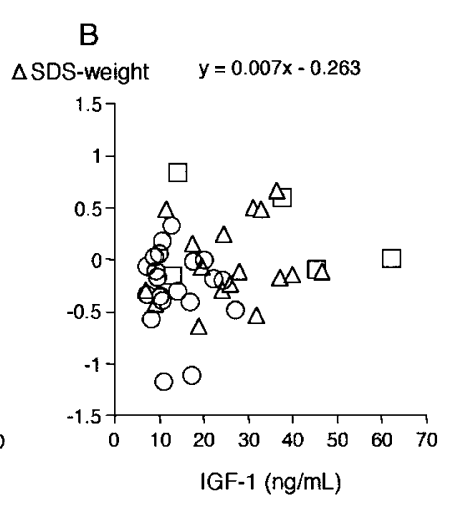

Figure 4. Correlations between serum IGF-I level and growth variables. Comparison between $\Delta$ SDS-length $(A)$ or $\Delta$ SDS-weight $(B)$ and mean value of serum IGF-I levels is shown. Positive correlation between serum IGF-I level and $\Delta$ SDS-length is presented but not $\Delta$ SDS-weight $\left(A: p=0.013, r^{2}=0.14\right.$; $\left.B: p=0.14, r^{2}=0.052\right)$. Symbols are the same as shown in Figure 3. 
patient population into two groups according to gestational age $(<28$ wk and $\geq 28$ wk of gestational age). The correlation between high serum GH and severity of ROP did not depend on gestational age in preterm infants (Table 3). Blood transfusion was marginally correlated with the development of ROP $(p=0.05)$ (Table 2).

\section{DISCUSSION}

Newborns show a state of GH resistance, characterized by GH hypersecretion and a low serum IGF-I level $(11,12)$. We observed that this unique profile was more prominent in extremely preterm infants and continued for 3 mo after birth. One of the factors to influence IGF-I production in the liver is the content and total calories of nutrition (19). Although preterm infants showed lower IGF-I levels (Fig. 2), there were no differences in the nutritional states among the three groups because of strict nutritional management in the neonatal intensive care unit (data not shown). Another explanation may include the functional immaturity of hepatocytes for IGF-I synthesis in preterm infants, resulting in acceleration of GH production in the pituitary gland by negative feedback process. A normalization of excess $\mathrm{GH}$ secretion in preterm infants might be caused either by an increased IGF-I level secondary to a maturation of $\mathrm{GH}$ receptor function or by an independent maturation of a somatostatinergic inhibitory mechanism.

GH and IGF-I are important growth factors for physical growth during childhood (20). However, the precise contributions of GH and IGF-I to the physical growth of newborn infants have not been defined. The present study clearly showed that IGF-I in the serum influenced physical growth during infancy of preterm infants, whereas GH did not. As the growth rate of preterm infants is slower than that of full-term infants $(1,17)$, we speculate that persistence of low IGF-I levels causes the slow growth rate of preterm infants. Additionally, regulatory factors for IGF-I function, such as circulating IGF-binding proteins (10), or other synergistic growth factors, including IGF-II, may also be involved in the growth of preterm infants. Thus, it is plausible that the measurement of serum IGF-I levels with other related factors predicts the physical growth rate of preterm infants within several months after birth. It was reported that supplement of milk-borne IGF-I apparently enhanced growth in newborn rats (21). Supplement of IGF-I by injection or oral administration may have a therapeutic potential for growth retardation in preterm infants. However, because IGF-I is likely to be important for VEGF-induced retinal neovascularization, as evidenced by inhibition of this process by an IGF-I receptor antagonist (22), further evaluation of the role of IGF-I in the pathogenesis of ROP is essential before use of this factor can be considered in this population.

GH functions as a pleiotropic factor and exerts its angiogenic ability in some pathologic conditions $(23,24)$. Several clinical studies showed that the pathogenesis of proliferative diabetic retinopathy was mediated by GH through its positive effect on the proliferation of endothelial cells (13-16). A previous case report demonstrated that patients with GH deficiency showed a reduced retinal vascularization during childhood (25), and GH replacement therapy for patients with GH deficiency induced diabeticlike retinopathy (26), which was remitted after discontinuation of GH treatment (27). In addition, GH and GH antagonist transgenic mice were shown to be susceptible to and protective against, respectively, hypoxia-induced neovascularization (28). Consistent with these previous findings, a high level of serum GH was associated with the development of severe ROP independent of the degree of immaturity in the present study. Taken together, GH

Table 2. Evaluation of risk factors for severe (stage $\geq 3$ ) ROP by multivariate analysis

\begin{tabular}{|c|c|c|c|c|c|c|}
\hline \multirow[b]{2}{*}{ Risk factor } & \multirow[b]{2}{*}{ Group 1/2 } & \multicolumn{2}{|c|}{ Group 1} & \multicolumn{2}{|c|}{ Group 2} & \multirow[b]{2}{*}{$p$ value } \\
\hline & & total $n$ & stage $\geq 3 n(\%)$ & total $n$ & stage $\geq 3 n(\%)$ & \\
\hline \multicolumn{7}{|l|}{$1 \mathrm{mo}$ of age } \\
\hline $\mathrm{GH}(\mathrm{ng} / \mathrm{mL})^{*}$ & $\geq 61.6 /<61.6$ & 22 & $9(40.9)$ & 31 & $1(3.2)$ & 0.026 \\
\hline IGF-I (ng/mL)* & $<15 / \geq 15$ & 21 & $8(38.1)$ & 32 & $2(6.3)$ & 0.38 \\
\hline CLD & $+/-$ & 19 & $7(36.8)$ & 34 & $3(8.8)$ & 0.30 \\
\hline Blood transfusion & $+1-$ & 18 & $8(44.4)$ & 35 & $2(5.7)$ & 0.05 \\
\hline
\end{tabular}

* Divided into two groups by medians of respective values.

Table 3. Relationship between GH and development of severe (stage $\geq 3$ ) ROP in two gestational age groups by Mantel-Haenszel analysis

\begin{tabular}{|c|c|c|c|c|c|c|}
\hline \multirow[b]{3}{*}{ Age } & \multirow[b]{3}{*}{ Groups* } & \multicolumn{4}{|c|}{ Gestational age } & \multirow[b]{3}{*}{$p$ value $\dagger$} \\
\hline & & \multicolumn{2}{|c|}{$<28$ wk } & \multicolumn{2}{|c|}{$\geq 28$ wk } & \\
\hline & & total $n$ & stage $\geq 3 n(\%)$ & total $n$ & stage $\geq 3 n(\%)$ & \\
\hline At birth & $\mathrm{L}$ & 11 & $3(27.3)$ & 8 & $2(25.0)$ & \\
\hline \multirow[t]{2}{*}{$1 \mathrm{mo}$} & $\mathrm{H}$ & 11 & $6(54.5)$ & 10 & $3(30.0)$ & 0.024 \\
\hline & $\mathrm{L}$ & 7 & $1(14.3)$ & 14 & $0(0.0)$ & \\
\hline \multirow[t]{2}{*}{$3 \mathrm{mo}$} & $\mathrm{H}$ & 7 & $5(71.4)$ & 1 & $1(100)$ & 0.040 \\
\hline & $\mathrm{L}$ & 5 & $0(0.0)$ & 3 & $1(33.3)$ & \\
\hline
\end{tabular}

* Divided into two groups $\mathrm{H}$ and $\mathrm{L}$ by each median value of $\mathrm{GH}$ at each point (at birth, $73.1 \mathrm{ng} / \mathrm{mL} ; 1 \mathrm{mo}, 61.6 \mathrm{ng} / \mathrm{mL} ; 2 \mathrm{mo}, 48.1 \mathrm{ng} / \mathrm{mL} ; 3 \mathrm{mo}, 42.6 \mathrm{ng} / \mathrm{mL}$ ).

$\dagger p$ value for comparison within same age group.

$\mathrm{H}, \geq$ median $\mathrm{GH}$ values; $\mathrm{L},<$ median GH values. 
may play an important role as an angiogenic growth factor in the development and progression of ROP in preterm infants. In addition, the development of ROP is affected by various environmental factors or medical treatments (29-34), including blood transfusion (33-35). As shown in Table 2, blood transfusion was marginally correlated with the development of ROP $(p=0.05)$. We speculate that anemia exacerbates retinal hypoxia, which stimulates retinal neovascularization, whereas frequent blood transfusion increases the delivery of oxygen to the retina as well as that of free iron, which induces retinal tissue damage, although the correlation between anemia or blood transfusion and ROP remains to be established (36). As another angiogenic factor, VEGF is intensively studied (37). In an animal study, production of VEGF induced by local retinal hypoxia has been reported to make a major contribution to the pathogenesis of neovascularization (38). Our preliminary study in preterm infants revealed no definite relationship between serum VEGF levels and development of ROP (data not shown). Therefore, it might be possible that GH functions as a systemic angioproliferative factor, whereas VEGF acts as a local angiogenic one $(38,39)$.

In conclusion, we showed that high GH and low IGF-I levels in the serum were observed in preterm infants, especially in extremely preterm infants. In addition, low IGF-I levels may explain the slow physical growth during the neonatal period of preterm infants. Furthermore, exposure to high GH may be involved, at least in part, in severity of ROP in preterm infants. If a role for $\mathrm{GH}$ in the development of ROP in preterm infants is confirmed, anti-GH treatment may have a therapeutic potential. Further evaluation will be needed to understand the pathogenesis of ROP in preterm infants, leading to the establishment of new treatment.

Acknowledgment. The authors thank Dr. Akinobu Matsuzaki for helpful discussions and advice.

\section{REFERENCES}

1. Sparks JW 1998 Infant growth in the first year of life. In: Polin RA, Fox WW (eds) Fetal and Neonatal Physiology, 2nd Ed. Philadelphia, Saunders, pp 291-295

2. Styne DM 1998 Fetal growth. Clin Perinatol 25:917-938

3. Baker J, Liu JP Robertson EJ, Efstratiadis A 1993 Role of insulin-like growth factors in embryonic and postnatal growth. Cell 75:73-82

4. Liu JP, Baker J, Perkins AS, Robertson EJ, Efstratiadis A 1993 Mice carrying null mutation of the genes encoding IGF I $(\operatorname{Ig} f-1)$ and type 1 IGF receptor $(\operatorname{Ig} f 1 r)$. Cell 75:59-72

5. Woods KA, Camacho-Hubner C, Savage MO, Clark AJ 1996 Intrauterine growth retardation and growth failure associated with deletion of the IGF I gene. N Engl J Med 335:1363-1367

6. Spencer JA, Chang TC, Jones J, Robson SC, Preece MA 1995 Third trimester fetal growth and umbilical venous blood concentrations of IGF-1, IGFBP-1, and GH at term. Arch Dis Child 73:F87-F90

7. Klauwer D, Blum WF, Hanitsch S, Rascher W, Lee PD, Kiess W 1997 IGF-I, IGF-II, free IGF-I and IGFBP-1, -2 and -3 levels in venous cord blood: relationship to birth weight, length and gestational age in healthy newborns. Acta Paediatr 86:826-833

8. Ogilvy-Stuart AL, Hands SJ, Adcock CJ, Holly JM, Matthews DR, Mohamed-Ali V, Yudkin JS, Wilkinson AR, Dunger DB 1998 Insulin, insulin-like growth factor I (IGF-I), IGF-binding protein-1, growth hormone, and feeding in the newborn. J Clin Endocrinol Metab 83:3550-3557

9. Cornbrath M, Parker ML, Reisner SH 1965 Secretion and metabolism of GH in premature and full-term infants. J Clin Endocrinol 25:209-218

10. Giudice LC, de Zegher F, Gargosky SE, Dsupin BA, de las Fuentes L, Crystal RA, Hintz RL, Rosenfeld RG 1995 Insulin-like growth factors and their binding proteins in the term and preterm human fetus and neonate with normal and extremes of intrauterine growth. J Clin Endocrinol Metab 80:1548-1555
11. Rajaram S, Carlson SE, Koo WW, Rangachari A, Kelly DP 1995 Insulin-like growth factor (IGF)-I and IGF-binding protein 3 during the first year in term and preterm infants. Pediatr Res 37:581-585

12. Radetti G, Bozzola M, Paganini C, Valentini R, Gentili L, Tettoni K, Tato L 1997 GH bioactivity and levels of GH, GH-binding protein, IGF I, and IGF-binding proteins in premature and full-term newborns during the first month of life. Arch Pediatr Adolesc Med 151:170-175

13. Wright AD, Kohner EM, Oakley NW, Hartog M, Joplin GF, Fraser TR 1969 Serum $\mathrm{GH}$ levels and the response of diabetic retinopathy to pituitary ablation. BMJ $2: 346-348$

14. Teuscher A, Escher F, Konig H, Zahnd G 1970 Long-term effects of transsphenoidal hypophysectomy on $\mathrm{GH}$, renal function and eyeground in patients with diabetic retinopathy. Diabetes 19:502-518

15. Gerich JE 1984 Role of GH in diabetes mellitus. N Engl J Med 310:848-850

16. Alzaid AA, Dinneen SF, Melton 3rd LJ, Rizza RA 1994 The role of GH in the development of diabetic retinopathy. Diabetes Care 17:531-534

17. Ogawa Y, Itabashi K 1996 Reference Growth Chart for Japanese Very Low Birth Weight Infants. Medicus Publishing Co, Osaka, pp 12-87 (in Japanese)

18. [No authors] 1984 An international classification of retinopathy of prematurity. The Committee for the Classification of Retinopathy of Prematurity. Arch Ophthalmol 102:1130-1134

19. Gautsch TA, Kandl SM, Donovan SM, Layman DK 1998 Response of the IGF-1 system to prolonged undernutrition and its involvement in somatic and skeletal muscle growth retardation in rats. Growth Dev Aging 62:13-25

20. Thorner MO, Vance ML, Laws Jr ER, Horvath E, Kovacs K 1998 The anterior pituitary. In: Wilson J, Foster D, Kronenberg H, Larsen P (eds) Williams Textbook of Endocrinology, 9th Ed. Philadelphia, Saunders, pp 256-263

21. Philipps AF, Anderson GG, Dvorak B, Williams CS, Lake M, Lebouton AV, Koldovsky O 1997 Growth of artificially fed infant rats: effect of supplementation with IGF I. Am J Physiol 272:R1532-R1539

22. Smith LE, Shen W, Perruzzi C, Soker S, Kinose F, Xu X, Robinson G, Driver S, Bischoff J, Zhang B, Schaeffer JM, Senger DR 1999 Regulation of vascular endothelial growth factor-dependent retinal neovascularization by IGF-1 receptor. Nat Med 5:1390-1395

23. Rymaszewski Z, Cohen RM, Chomczynski P 1991 hGH stimulates proliferation of human retinal microvascular endothelial cells in vitro. Proc Natl Acad Sci USA 88:617-621

24. Struman I, Bentzien F, Lee H, Mainfroid V, D'Angelo G, Goffin V, Weiner RI, Martial JA 1999 Opposing actions of intact and N-terminal fragments of the human prolactin/GH family members on angiogenesis: an efficient mechanism for the regulation of angiogenesis. Proc Natl Acad Sci USA 96:1246-1251

25. Hellstrom A, Svensson E, Carlsson B, Niklasson A, Albertsson-Wikland K 1999 Reduced retinal vascularization in children with GH deficiency. J Clin Endocrinol Metab 84:795-798

26. Koller EA, Green L, Gertner JM, Bost M, Malozowski SN 1998 Retinal changes mimicking diabetic retinopathy in two nondiabetic, GH-treated patients. J Clin Endocrinol Metab 83:2380-2383

27. Hansen R, Koller EA, Malozowski S 2000 Full remission of growth hormone (GH)-induced retinopathy after $\mathrm{GH}$ treatment discontinuation: long term follow-up. [letter] J Clin Endocrinol Metab 85:2627

28. Smith LE, Kopchick JJ, Chen W, Knapp J, Kinose F, Daley D, Foley E, Smith RG, Schaeffer JM 1997 Essential role of GH in ischemia-induced retinal neovascularization. Science 276:1706-1709

29. Batton DG, Roberts C, Trese M, Maisels MJ 1992 Severe retinopathy of prematurity and steroid exposure. Pediatrics 90:534-536

30. Gallo JE, Jacobson L, Broberger U 1993 Perinatal factors associated with retinopathy of prematurity. Acta Paediatr 82:829-834

31. Termote JU, Schalij-Delfos NE, Wittebol-Post D, Brouwers HA, Hoogervorst BR, Cats BP 1994 Surfactant replacement therapy: a new risk factor in developing retinopathy of prematurity? Eur J Pediatr 153:113-116

32. Holmstrom G, Thomassen P, Broberger U 1996 Maternal risk factors for retinopathy of prematurity - a population-based study. Acta Obstet Gynecol Scand 75:628-635

33. Hesse L, Eberl W, Schlaud M, Poets CF 1997 Blood transfusion. Iron load and retinopathy of prematurity. Eur J Pediatr 156:465-470

34. Inder TE, Clemett RS, Austin NC, Graham P, Darlow BA 1997 High iron status in very low birth weight infants is associated with an increased risk of retinopathy of prematurity. J Pediatr 131:541-544

35. Cooke RW, Clark D, Hickey-Dwyer M, Weindling AM 1993 The apparent role of blood transfusions in the development of retinopathy of prematurity. Eur J Pediatr 152:833-836

36. Brooks SE, Marcus DM, Gillis D, Pirie E, Johnson C, Bhatia J 1999 The effect of blood transfusion protocol on retinopathy of prematurity: a prospective, randomized study. Pediatrics 104:514-418

37. Donahue ML, Phelps DL, Watkins RH, LoMonaco MB, Horowitz S 1996 Retinal vascular endothelial growth factor (VEGF) mRNA expression is altered in relation to neovascularization in oxygen induced retinopathy. Curr Eye Res 15:175-184

38. Pierce EA, Foley ED, Smith LE 1996 Regulation of vascular endothelial growth factor by oxygen in a model of retinopathy of prematurity. Arch Ophthalmol 114:1219-1228

39. Meyer-Schwickerath R, Pfeiffer A, Blum WF, Freyberger H, Klein M, Losche C, Rollmann R, Schatz H 1993 Vitreous levels of the insulin-like growth factors I and II, and the IGF binding proteins 2 and 3, increase in neovascular eye disease. Studies in nondiabetic and diabetic subjects. J Clin Invest 92:2620-2625 